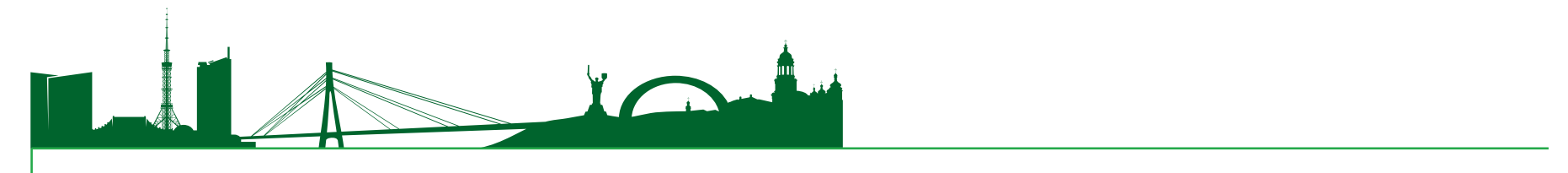

УДК 624.012.45

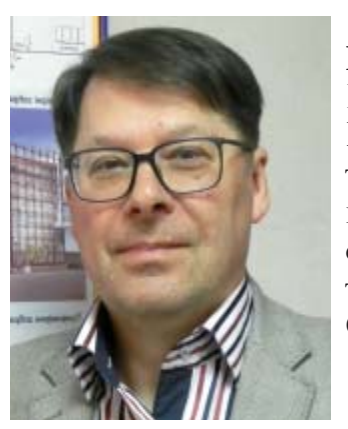

ВОЙЦЕХІВСЬКИЙ О.В.

Канд. технічних наук, доц., Вінницький національний технічний університет,

м. Вінниця, Україна,

e-mail: Voicehvinn@gmail.com, тел.: + 38 (067) 430-56-64,

ORCID: 0000-0003-2764-9996

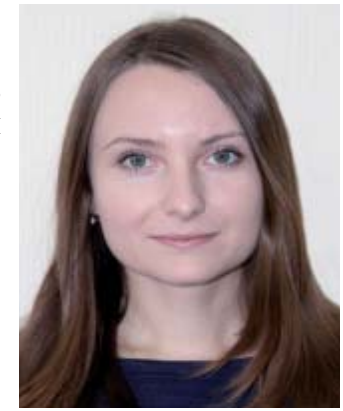

ГАВРИЛИШЕНА Т.В.

Магістр, ТОВ «Гервін МЗ»,

м. Вінниця, Україна,

e-mail:Kondratenko09059@gmail.com,

тел.: + 38 (093) 948-64-49,

ORCID: 0000-0003-1795-3660

\title{
ПЕРЕВІРОЧНИЙ РОЗРАХУНОК ПРОГИНІВ ЗА СПРОЩЕНИМИ ДІАГРАМАМИ ЗА ДБН В.2.6-98:2009 «БЕТОННІ ТА ЗААІЗОБЕТОННІ КОНСТРУКЦІЇ. ОСНОВНІ ПОЛОЖЕННЯ»
}

\section{АНОТАЦІЯ}

За вимогами чинних норм проектування залізобетонних конструкцій допускається використовувати спрощену дволінійну діаграму деформування матеріалів. Попередньо була описана методика розрахунку залізобетонної балки за першою групою граничних станів із використанням спрощених діаграм деформування матеріалів. Тому в цій статті розглянуто методику розрахунку за другою групою граничних станів із контролю прогинів 3 використанням спрощених діаграм деформування матеріалів, що приймаються згідно основних вимог.

Згідно з п. 7.4.4.1 ДБН В.2.6-98:2009 «Бетонні та залізобетонні конструкції. Основні положення» основною є умова забезпечення жорсткості. Враховуючи залежність прогину балки як від жорсткості, так і від величини зовнішнього навантаження, перевірка буде полягати у порівнянні моментів від зовнішнього навантаження та від дії максимально допустимого експлуатаційного навантаження. Напружено-деформований стан нормального перерізу розглядається із урахуванням стадії роботи розтягнутої та стиснутої арматури.

Алгоритм розрахунку передбачає такі операції:

- визначення гранично допустимого значення кривизни балки через максимальний прогин;

- знаходження висоти стиснутої зони бетону із попереднього припущення, що розтягнута та стиснута арматура працюють в стадії текучості;

- перевірка правильності цього припущення через знаходження деформацій в арматурі.

у випадку помилкового припущення, методом поступового підбору, виконання перевірки наступних можливих варіантів напружено-деформованих станів арматури при конкретних проектних умо- вах. Знаходження максимального експлуатаційного моменту та порівняння його 3 зовнішнім діючим моментом.

КАЮЧОВІ СЛОВА: жорсткість балки, прогин, спрощені діаграми деформування, стадії роботи арматури.

\section{ПРОВЕРОЧНЫЙ РАСЧЕТ ПРОГИБОВ ПО УПРОЩЁННЫМ ДИАГРАММАМ ПО ДБН В.2.6-98:2009 «БЕТОННЫЕ И ЖЕАЕЗОБЕТОННЫЕ КОНСТРУКЦИИ. ОСНОВНЫЕ ПОЛОЖЕНИЯ»}

ВОЙЦЕХОВСКИЙ А.В. Канд. технических наук, доц., Винницкий национальный технический университет,

г. Винница, Украина,

e-mail: Voicehvinn@gmail.com,

тел.: + 38 (067) 430-56-64,

ORCID: 0000-0003-2764-9996

ГАВРИАИШЕНА Т.В. Магистр, ООО «Гервин МЗ», г. Винница, Украина,

e-mail: Kondratenko09059@gmail.com,

тел.: + 38 (093) 948-64-49,

ORCID: 0000-0003-1795-3660

\section{АННОТАЦИЯ}

Согласно требований действующих норм проектирования железобетонных конструкций допускается использовать упрощённую дволинейную диаграмму деформирования материалов. Ранее была описана методика расчета железобетонной балки по первой группе предельных состояний с использованием упрощённых диаграмм материалов. Поэтому 
в этой статье рассмотрено методику расчета по второй группе предельных состояний из контроля прогибов с использованием упрощённых диаграмм деформирования материалов, которые принимаются с учетом нормативов.

Согласно п. 7.4.4.1 ДБН В.2.6-98:2009 «Бетонные и железобетонные конструкции. Основные положения» главным есть условие обеспечения жесткости. Учитывая зависимость прогиба балки как от жесткости, так и от величины внешней нагрузки, проверка будет состоять из сравнения моментов от внешней нагрузки и от действия максимально допустимой эксплуатационной нагрузки. Напряженнодеформированное состояние нормального сечения рассматривается с учетом стадии работы растянутой и сжатой арматуры.

Алгоритм расчета предусматривает такие операции. Определение граничного значения кривизны балки через максимальный прогиб. Нахождение высоты сжатой зоны бетона из предположения, что растянутая и сжатая арматура работают в стадии текучести. Проверка правильности этого предположения нахождением деформаций в арматуре. В случае ошибочного предположения, методом постепенного подбора, выполнение проверки следующих возможных вариантов напряженнодеформированных состояний арматуры в конкретных проектных условиях. Нахождение максимального эксплуатационного момента и сравнение его с внешним действующим моментом.

КЛЮЧЕВЫЕ CЛОВА: жесткость балки, прогиб, упрощенные диаграммы деформирования, стадии работы арматуры.

\section{GHEKING GALCULATION OF DEFLECTIONS USING SIMPLIFIED DEFORMATION DIAGRAMS ACCORDING TO DBN V.2.6-98:2009 «CONCRETE AND REINFORCED CONGRETE STRUCTURES. GENERAL PROVISIONS»}

VOITSEKHIVSKYI O.V. PhD, Ass. Prof., Vinnytsia National Technical University,

Vinnytsia, Ukraine,

e-mail: Voicehvinn@gmail.com,

tel.: + 38 (067) 430-56-64,

ORCID: 0000-0003-2764-9996

HAVRYLYSHENA T.V. Master, TOV "Gervin MZ",

Vinnytsia, Ukraine,

e-mail: Kondratenko09059@gmail.com,

tel.: + 38 (093) 948-64-49,

ORCID: 0000-0003-1795-3660

\section{ABSTRACT}

It is allowed to use simplified bilinear deformation diagrams for materials according to the requirements of current design standards for reinforced concrete structures. Previously, a ULS calculation procedure for reinforced concrete beam using simplified deformation diagrams has been described. Therefore this article covers a SLS calculation procedure for deflection control using simplified deformation diagrams of materials which are considered taking into account basic requirements. According to para. 7.4.4.1, DBN V.2.6-98:2009 «Concrete and reinforced concrete structures. General provisions», the rigidity is the main condition. Considering the fact that the beam deflection depends both from the rigidity and the external load, the verification consists of comparing the external load moments and those of the maximum allowable service load. The stress strain state of normal section is considered taking into account work stages of tension and compression reinforcement. The calculation algorithm allows for the following operations. Determination of the maximum permissible value of beam deflection using the maximum deflection. Height fixation of the compressed concrete zone taking into account the previous assumption that tension and compression reinforcement act in yield stage. Checking the accuracy of this assumption by determining strains of the reinforcement. In the case of a false assumption, the verification of the following possible options of reinforcement stress strain behavior in the specific design conditions using trial and error method. Finding the maximum operation moment and comparing it with the external moment acting now.

KEY WORDS: beam rigidity, deflection, simplified deformation diagrams of material, work stages of reinforcement.

\section{ВСТУП}

У відповідності до п. 7.4.3.1 [1] визначити прогин потрібно із застосуванням діаграм стану бетону та арматури. Так як спрощені діаграми деформування матеріалів можуть використовуватись для першої групи граничних станів, що було описано в [2], так і для другої групи граничних станів, для виконання перевірочних розрахунків, або близьких до них, у цій статті використано методику розрахунку прогину із використанням спрощених діаграм деформування матеріалів.

Розрахунок залізобетонних елементів за деформаціями виконується після того, як було виконано співставлення співвідношення проліт/висота (l/h) згідно з п. 5.4.2 [3] та отримано висновок щодо необхідності проведення такого розрахунку. Для того, щоб перевірити забезпечення жорсткості, порівняємо моменти від зовнішнього навантаження та максимально допустимого при експлуатації, що мають пряму залежність від прогину балки. Суть даної методики полягає у використанні методу підбору стадії роботи арматури у розрахунках при розгляді напружено-деформованого стану перерізу. Як результат, такий розрахунок повинен відображати фактичний характер роботи конструкції при відповідних сполученнях дій із точністю, що необхідна для досягнення заданої мети. 


\section{META}

Метою дослідження $є$ розробка методики 3 перевірки жорсткості залізобетонних балок, в яких співвідношення $\mathrm{l} / \mathrm{h} \geq 20$. Для таких балок, при визначенні площі робочого армування, головним $є$ не розрахунок несучої здатності за першою групою граничних станів, а 3 перевірки прогинів. Особливо це важливо для залізобетонних балок, у яких відсоток армування більше 1,2-2\%.

\section{ПОСТАНОВКА ЗАВДАННЯ}

Ця методика може бути цілком виправдана для проведення експертних, попередніх оцінювальних або учбових задач, тому завдання представлено у вигляді задачі.

Дано: розрахункова схема балки, іiі розрахункова довжина 10 (м); розподілене навантаження q (кН/м) від дії зовнішніх навантажень. Задано розміри прямокутного перерізу $\mathrm{b} \times \mathrm{h}(\mathrm{M} \times \mathrm{M})$, клас бетону С та арматурної сталі A, кількість та розташування робочої розтягнутої $\mathrm{A}_{\mathrm{s}}\left(\mathrm{cm}^{2}\right), \mathrm{a}_{\mathrm{s}}(\mathrm{cm})$ та стиснутої $\mathrm{A}_{\mathrm{s}}{ }^{\prime}\left(\mathrm{cm}^{2}\right), \mathrm{a}_{\mathrm{s}}{ }^{\prime}(\mathrm{cm})$ арматури.

Необхідно визначити:

- момент, що діє в перерізі при заданому навантаженні $\mathrm{M}_{\mathrm{Ed}}$;

- момент, що виникає в нормальному перерізі балки при максимально допустимому експлуатаційному прогині $\mathrm{M}_{\text {Ехр.u }}$;

- як працює робоча розтягнута та стиснута арматура при дії $\mathrm{M}_{\text {Ехр. }}$;

- перевірити умову забезпечення жорсткості.

Перевірка умови забезпечення жорсткості

Згідно з основними вимогами п.7.4.4.1 [2] умова забезпечення жорсткості визначається за формулою:

$$
\mathrm{f} \leq \mathrm{f}_{\mathrm{u}}
$$

де $\mathrm{f}$ - прогин балки; $\mathrm{f}_{\mathrm{u}}$ - граничний прогин.

Враховуючи те, що прогин балки f залежить як від жорсткості перерізу конструкції, так і від величини зовнішнього навантаження, що діє на балку у вигляді моменту, умова може мати вид:

$$
\mathrm{M}_{\mathrm{Ed}} \leq \mathrm{M}_{\text {Exp.u}} \text {, }
$$

де $\mathrm{M}_{\mathrm{Ed}}$ - момент в перерізі від зовнішнього навантаження; $\mathrm{M}_{\text {Ехр.и }}$ - момент в перерізі, що виникає при дії максимально допустимого експлуатаційного навантаження.

Момент від фактичного зовнішнього навантаження знаходиться за відомою формулою:

$$
\mathrm{M}_{\mathrm{Ed}}=\mathrm{q} \cdot 102 / 8
$$

Момент $\mathrm{M}_{\text {Ехр.u }}$ знаходиться із розгляду напружено-деформованого стану нормального перерізу, що виникає при дії максимально допустимого експлуатаційного навантаження.

Максимально можливе експлуатаційне навантаження виникає, коли прогин балки буде дорівнювати значенню $\mathrm{f}_{\mathrm{u}}$.

Якщо умова (2) виконується, то жорсткість балки є забезпеченою.

Якщо умова (2) не виконується, умова жорсткості не забезпечується.

\section{Напружено-деформований стан перерізу}

Напружено-деформований стан нормального перерізу балки представлено на рис. 1.

Максимальнодопустимий момент при експлуатації дорівнює

$$
\mathrm{M}_{\text {Exp.u }}=\mathrm{F}_{\mathrm{c}}\left(\mathrm{d}-\lambda \cdot \mathrm{x}_{1}\right)+\mathrm{F}_{\mathrm{s}}{ }^{\prime}\left(\mathrm{d}-\mathrm{a}_{\mathrm{s}}{ }^{\prime}\right)
$$

де $\mathrm{F}_{\mathrm{s}}$ - - зусилля в стиснутій арматурі, що визначається залежно від стадії роботи стиснутої арматури;

$$
\lambda=\left(\varepsilon_{\mathrm{cu} 3 . \mathrm{ck}}-\varepsilon_{\mathrm{c} 3 . \mathrm{ck}}\right) / \varepsilon_{\mathrm{cu} 3 . \mathrm{c}} \mathrm{k} .
$$

У випадку одиночного армування

де

$$
\mathrm{M}_{\text {Exp.u }}=\mathrm{F}_{\mathrm{c}}\left(\mathrm{d}-\lambda \cdot \mathrm{x}_{1}\right) \text {. }
$$

$$
\begin{gathered}
\mathrm{F}_{\mathrm{c}}=\mathrm{q}_{\mathrm{c}} \cdot \mathrm{x}_{1}, \\
\mathrm{q}_{\mathrm{c}}=0,5 \mathrm{~b} \cdot \mathrm{f}_{\mathrm{ck}}(1+\lambda) .
\end{gathered}
$$

Прив'яжемо знаходження висоти стиснутої зони бетону $\mathrm{x}_{1}$ та зусиль в стиснутій $\mathrm{F}_{\mathrm{s}}$ ' та розтягнутій $\mathrm{F}_{\mathrm{s}}$ арматурі до величини гранично допустимого значення прогину $\mathrm{f}_{\mathrm{u}}$.

Для цього спочатку визначимо кривизну $(1 / \rho)_{u}$, що виникає в перерізі при прогині $\mathrm{f}_{\mathrm{u}}$.

Кривизна перерізу (1/p) при максимально допустимому значенні прогину $\mathbf{f}_{\mathrm{u}}$

3 одного боку, згідно з п. 7.4.4.5 [2] гранично допустиме значення прогину $\mathrm{f}_{\mathrm{u}}$ слід призначати a)

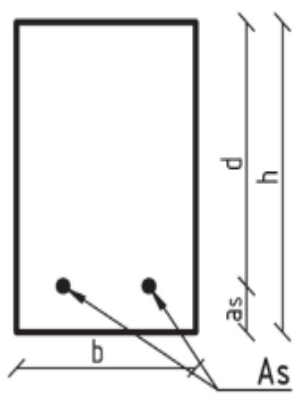

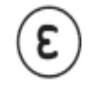

$$
\text { ठ) }
$$

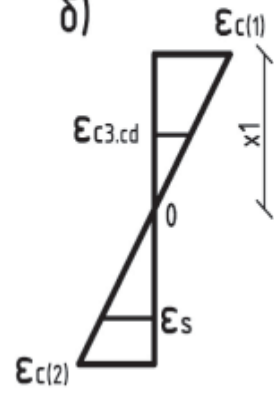

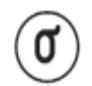

Рис. 1. Поперечний переріз (а) та напружено-деформований стан (б) нормального перерізу балки з одиночним армуванням 
згідно 3 [3]. При дії постійних та змінних тривалих, a також i короткочасних навантажень це значення для балок на двох опорах має не перевищувати 1/150 прольоту. Тобто

$$
\mathrm{f}_{\mathrm{u}} \leq 1 / 150 \cdot \mathrm{l}_{0}
$$

3 іншого боку, для статично визначених балок із розподільчою схемою навантажень

$$
\mathrm{F}=(1 / \rho) \mathrm{k}_{\mathrm{m}} \cdot \mathrm{l}_{0}^{2}=(1 / \rho) 5 / 48 \cdot \mathrm{l}_{0}^{2}
$$

Тоді кривизна балки при дії максимально допустимого експлуатаційного навантаження буде дорівнювати

$$
(1 / \rho)_{\mathrm{u}}=1 /\left(15,625 \cdot 1_{0}\right)
$$

Висота стиснутої зони бетону $\mathbf{x}_{1}$ залежно від різних можливих варіантів роботи розтягнутої та стиснутої арматури

При одиночному армуванні в залізобетонному перерізі можуть відбуватись два характерних випадки роботи арматури.

Випадок 1 - коли в розтягнутій арматурі відбувається текучість, тобто

$$
\left\{\begin{array}{l}
\varepsilon_{\mathrm{s} 0} \leq \varepsilon_{\mathrm{s}}<\varepsilon_{\mathrm{ud}} \\
\mathrm{F}_{\mathrm{s}}=\mathrm{f}_{\mathrm{yk}} \cdot \mathrm{A}_{\mathrm{s}}
\end{array}\right.
$$

Випадок 2 - коли розтягнута арматура працює пружно, тобто

$$
\left\{\begin{array}{l}
0<\varepsilon_{\mathrm{s}}<\varepsilon_{\mathrm{s} 0} \\
\mathrm{~F}_{\mathrm{s}}=\varepsilon_{\mathrm{s}} \cdot \mathrm{E}_{\mathrm{s}} \cdot \mathrm{A}_{\mathrm{s}}
\end{array}\right.
$$

При подвійному армуванні перерізу можуть відбуватись чотири характерні випадки залежно від стадії роботи робочої арматури в розтягнутій та стиснутій зонах бетону.

Випадок 1.1 - робоча розтягнута і стиснута арматура працює на стадії текучості, тобто

$$
\left\{\begin{array} { l } 
{ \varepsilon _ { \mathrm { s } 0 } \leq \varepsilon _ { \mathrm { s } } < \varepsilon _ { \mathrm { ud } } , } \\
{ \mathrm { F } _ { \mathrm { s } } = \mathrm { f } _ { \mathrm { yk } } \cdot \mathrm { A } _ { \mathrm { s } } . }
\end{array} \text { та } \left\{\begin{array}{l}
\varepsilon_{\mathrm{s} 0}{ }^{\prime} \leq \varepsilon_{\mathrm{s}}{ }^{\prime}<\varepsilon_{\mathrm{ud}}{ }^{\prime}, \\
\mathrm{F}_{\mathrm{s}}{ }^{\prime}=\mathrm{f}_{\mathrm{yk}}{ }^{\prime} \cdot \mathrm{A}_{\mathrm{s}}{ }^{\prime} .
\end{array}\right.\right.
$$

Випадок 1.2 - робоча розтягнута арматура працює на стадії текучості, а арматура в стиснутій зоні працює пружно, тобто

$$
\left\{\begin{array} { l } 
{ \varepsilon _ { \mathrm { s } 0 } \leq \varepsilon _ { \mathrm { s } } < \varepsilon _ { \mathrm { ud } } , } \\
{ \mathrm { F } _ { \mathrm { s } } = \mathrm { f } _ { \mathrm { yk } } \cdot \mathrm { A } _ { \mathrm { s } } . }
\end{array} \text { та } \left\{\begin{array}{l}
0<\varepsilon_{\mathrm{s}}{ }^{\prime}<\varepsilon_{\mathrm{s} 0}{ }^{\prime}, \\
\mathrm{F}_{\mathrm{s}}{ }^{\prime}=\varepsilon_{\mathrm{s}}{ }^{\prime} \cdot \mathrm{E}_{\mathrm{s}}{ }^{\prime} \cdot \mathrm{A}_{\mathrm{s}}{ }^{\prime} .
\end{array}\right.\right.
$$

Випадок 2.1 - робоча розтягнута арматура працює пружно, а арматура в стиснутій зоні знаходиться в стадії текучості, тобто

$$
\left\{\begin{array} { l } 
{ 0 < \varepsilon _ { \mathrm { s } } < \varepsilon _ { \mathrm { s } 0 } , } \\
{ \mathrm { F } _ { \mathrm { s } } = \varepsilon _ { \mathrm { s } } \cdot \mathrm { E } _ { \mathrm { s } } \cdot \mathrm { A } _ { \mathrm { s } } ; }
\end{array} \text { , } \left\{\begin{array}{l}
\varepsilon_{\mathrm{s} 0}{ }^{\prime} \leq \varepsilon_{\mathrm{s}}{ }^{\prime}<\varepsilon_{\mathrm{ud}}{ }^{\prime}, \\
\mathrm{F}_{\mathrm{s}}{ }^{\prime}=\mathrm{f}_{\mathrm{yk}}{ }^{\prime} \cdot \mathrm{A}_{\mathrm{s}}{ }^{\prime} .
\end{array}\right.\right.
$$

Випадок 2.2 - робоча розтягнута і стиснута арматура працюють пружно, тобто

$$
\left\{\begin{array} { l } 
{ 0 < \varepsilon _ { \mathrm { s } } < \varepsilon _ { \mathrm { s } 0 } , } \\
{ \mathrm { F } _ { \mathrm { s } } = \varepsilon _ { \mathrm { s } } \cdot \mathrm { E } _ { \mathrm { s } } \cdot \mathrm { A } _ { \mathrm { s } } ; }
\end{array} \text { , } { } ^ { 2 } \left\{\begin{array}{l}
0<\varepsilon_{\mathrm{s}}{ }^{\prime}<\varepsilon_{\mathrm{s} 0}{ }^{\prime}, \\
\mathrm{F}_{\mathrm{s}}{ }^{\prime}=\varepsilon_{\mathrm{s}}{ }^{\prime} \cdot \mathrm{E}_{\mathrm{s}}{ }^{\prime} \cdot \mathrm{A}_{\mathrm{s}}{ }^{\prime} .
\end{array}\right.\right.
$$

В той же час, виходячи із лінійності розподілу деформацій по висоті перерізу, отримаємо:

- деформації стиснутої арматури

$$
\varepsilon_{\mathrm{s}}^{\prime}=(1 / \rho)_{\mathrm{u}}\left(\mathrm{x}_{1}-\mathrm{a}_{\mathrm{s}}^{\prime}\right)
$$

- деформації розтягнутої арматури

$$
\varepsilon_{\mathrm{s}}=(1 / \rho)_{\mathrm{u}}\left(\mathrm{d}-\mathrm{x}_{1}\right)
$$

Визначимо висоту стиснутої зони бетону $\mathrm{x}_{1}$ при різних типах роботи робочої арматури.

При характерному типі 1 , коли виконується умова (11), висота стиснутої зони бетону

$$
\mathrm{x}_{1}=\mathrm{f}_{\mathrm{yk}} \cdot \mathrm{A}_{\mathrm{s}} / \mathrm{q}_{\mathrm{c}}
$$

При характерному типі 2, коли виконується умова (12), висота стиснутої зони бетону

$$
x_{1}=\left((1 / \rho)_{u} \cdot d \cdot E_{s} \cdot A_{s}\right) /\left((1 / \rho)_{u} \cdot E_{s} \cdot A_{s}+q_{c}\right) .
$$

При характерному типі 1.1, коли має виконуватись умова (13), висота стиснутої зони бетону

$$
\mathrm{x}_{1}=\left(\mathrm{f}_{\mathrm{yk}} \cdot \mathrm{A}_{\mathrm{s}}-\mathrm{f}_{\mathrm{yk}} \cdot \mathrm{A}_{\mathrm{s}}{ }^{\prime}\right) / \mathrm{q}_{\mathrm{c}} \cdot
$$

При характерному типі 1.2 , коли виконується умова (14), висота стиснутої зони бетону

$$
x_{1}=\left(f_{y k} \cdot A_{s}+(1 / \rho)_{u} \cdot a_{s}^{\prime} \cdot E_{s}^{\prime} \cdot A_{s}^{\prime}\right) /\left((1 / \rho)_{u} \cdot E_{s}^{\prime} \cdot A_{s}^{\prime}+q_{c}\right)
$$

При характерному типі 2.1, коли виконується умова (15), висота стиснутої зони бетону

$$
\mathrm{x}_{1}=\left((1 / \rho)_{\mathrm{u}} \cdot \mathrm{d} \cdot \mathrm{E}_{\mathrm{s}} \cdot \mathrm{A}_{\mathrm{s}}-\mathrm{f}_{\mathrm{yk}}{ }^{\prime} \cdot \mathrm{A}_{\mathrm{s}}{ }^{\prime}\right) /\left((1 / \rho)_{\mathrm{u}} \cdot \mathrm{E}_{\mathrm{s}} \cdot \mathrm{A}_{\mathrm{s}}+\mathrm{q}_{\mathrm{c}}\right) .
$$

При характерному типі 2.2, коли виконується умова (16), висота стиснутої зони бетону

$$
\mathrm{x}_{1}=(1 / \rho)_{\mathrm{u}}\left(\mathrm{d} \cdot \mathrm{E}_{\mathrm{s}} \cdot \mathrm{A}_{\mathrm{s}}+\mathrm{a}_{\mathrm{s}} \cdot \mathrm{E}_{\mathrm{s}} \cdot \mathrm{A}_{\mathrm{s}}{ }^{\prime}\right) /\left((1 / \rho)_{\mathrm{u}}\left(\mathrm{E}_{\mathrm{s}} \cdot \mathrm{A}_{\mathrm{s}}+\mathrm{E}_{\mathrm{s}}{ }^{\prime} \cdot \mathrm{A}_{\mathrm{s}}{ }^{\prime}\right)+\mathrm{q}_{\mathrm{c}}\right) .
$$

Суть розрахунку полягає в тому, що поступово визначають висоту стиснутої зони бетону $\mathrm{x}_{1}$ за формулами (20-25) і кожного разу перевіряється правильність прийнятого припущення відповідно до формул (12-17). Тобто, деформації в розтягнутій та стиснутій арматурі, що знаходяться із умови 
рівноваги суми сил на вісь $\mathrm{X}$, мають відповідати заданому рівню навантаження та гранично допустимому значенню прогину $\mathrm{f}_{\mathrm{u}}$.

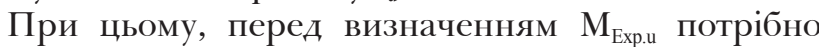
обов'язково перевірити умову, що деформації в стиснутій зоні бетону не перевищують граничні значення

$$
\varepsilon_{\mathrm{cl}} \leq \varepsilon_{\mathrm{cu} 3 . \mathrm{ck}}
$$

де $\varepsilon_{\mathrm{c} 1}$ знаходимо із розгляду напруженодеформованого стану перерізу (рис. 1, б) за формулою:

$$
\varepsilon_{\mathrm{cl}}=\mathrm{x}_{1} \cdot \varepsilon_{\mathrm{s}} /\left(\mathrm{d}-\mathrm{x}_{1}\right)
$$

Нижче приведений приклад розрахунку за розробленим алгоритмом вирішення задач даною методикою.

Для перевірки достовірності результатів паралельно проводили розрахунок за повною діаграмою деформування матеріалів.

Вихідні дані:

\section{Приклад розрахунку}

$\begin{array}{ll}\text { Бетон C25/30, } \gamma_{\mathrm{cl}}=1,0 & \text { Арматура A 400C } \\ \mathrm{b}=30 \mathrm{~cm}, \mathrm{~h}=60 \mathrm{~cm} & \mathrm{~A}_{\mathrm{s}}=6 \varnothing 32, \mathrm{a}_{\mathrm{s}}=50 \mathrm{Mm} \\ \mathrm{q}=50 \mathrm{KH} / \mathrm{M}, \mathrm{l}=12200 \mathrm{~mm} & \mathrm{~A}_{\mathrm{s}}^{\prime}=3 \varnothing 16, \mathrm{a}_{\mathrm{s}}^{\prime}=50 \mathrm{Mm}\end{array}$

Розв'язання:

1. Фізико-механічні характеристики:

- для бетону $\mathrm{f}_{\mathrm{ck}}=22$ МПа, $\varepsilon_{\mathrm{cu}, \mathrm{ck}}=320 \cdot 10^{-5}$, $\varepsilon_{\mathrm{c} 3, \mathrm{ck}}=76 \cdot 10^{-5}$;

- для розтягнутої арматури $\mathrm{f}_{\mathrm{yk}}=400 \mathrm{MПа,} \gamma_{\mathrm{s}}=1,1$, $\mathrm{E}_{\mathrm{s}}=2,1 \cdot 10^{5} \mathrm{M \Pi а}, \varepsilon_{\text {ud }}=2500 \cdot 10^{-5}$;

- для стиснутої арматури $\mathrm{f}_{\mathrm{yk}}{ }^{\prime}=400 \mathrm{MПа,} \gamma_{\mathrm{s}}{ }^{\prime}=1,1$, $\mathrm{E}_{\mathrm{s}}{ }^{\prime}=2,1 \cdot 10^{5} \mathrm{M \Pi а}, \varepsilon_{\text {ud }}{ }^{\prime}=2500 \cdot 10^{-5}$.

2. Гранично допустиме значення прогину $\mathrm{f}_{\mathrm{u}}$ як для балки, вільно обпертої по краям

$$
\mathrm{f}_{\mathrm{u}}=12200 / 150=81,33 \mathrm{мм} \text {. }
$$

3. Кривизна перерізу

$$
(1 / \rho)_{\text {exp.u }}=0,08133 /\left(5 / 48 \cdot 1,2^{2}\right)=0,0052(1 / \mathrm{M}) .
$$

$$
\begin{aligned}
& \text { 4. Визначаємо величини: } \\
& \mathrm{d}=0,6-0,05=0,55 \mathrm{~m} ; \varepsilon_{\mathrm{s0}}=400 \cdot 10^{3} /\left(2,1 \cdot 10^{8}\right)=190 \cdot 10^{-5} \\
& \varepsilon_{\mathrm{s} 0}{ }^{\prime}=400 \cdot 10^{3} /\left(2,1 \cdot 10^{8}\right)=190 \cdot 10^{-5} ; \\
& \lambda=\left(320 \cdot 10^{-5}-76 \cdot 10^{-5}\right) / 320 \cdot 10^{-5}=0,76 .
\end{aligned}
$$

5. Величина усереднених внутрішніх розподілених напружень у стиснутій зоні бетону

$$
\mathrm{q}_{\mathrm{c}}=0,5 \cdot 22 \cdot 10^{3} \cdot 0,3(1+0,76)=5808(\kappa \mathrm{H} / \mathrm{M}) .
$$

6. Висота стиснутої зони бетону $\mathrm{x}_{1}=\left(400 \cdot 10^{3} \cdot 48,23 \cdot 10^{-4}-400 \cdot 10^{3} \cdot 6,03 \cdot 10^{-4}\right) / 5808=0,264(\mathrm{M})$.

7. Деформації в стиснутій та розтягнутій арматурі $\varepsilon_{\mathrm{s}}{ }^{\prime}=0,0052(0,264-0,05)=111,28 \cdot 10^{-5}$;

$$
\varepsilon_{\mathrm{s}}=0,0052(0,55-0,264)=148,72 \cdot 10^{-5} .
$$

8. Перевіряємо умову (13)

$$
\left\{\begin{array}{l}
\varepsilon_{\mathrm{s} 0}=190 \cdot 10^{-5}>\varepsilon_{\mathrm{s}}=148,72 \cdot 10^{-5} \\
\varepsilon_{\mathrm{s} 0}{ }^{\prime}=190 \cdot 10^{-5}>\varepsilon_{\mathrm{s}}{ }^{\prime}=111,28 \cdot 10^{-5}
\end{array}\right.
$$

та робимо висновок, що умова не виконана - розтягнута арматура працює в пружній стадії, стиснута арматура працює в пружній стадії. Тому виконуємо перерахунок згідно випадку 2.2.

9. Висота стиснутої зони бетону

$$
\begin{gathered}
\mathrm{x}_{1}=0,0052\left(0,55 \cdot 2,1 \cdot 10^{8} \cdot 48,23 \cdot 10^{-4}+0,05 \cdot 2,1 \cdot 10^{8} \times\right. \\
\left.\times 6,03 \cdot 10^{-4}\right) /\left(0,0052\left(2,1 \cdot 10^{8} \cdot 48,23 \cdot 10^{-4}+2,1 \cdot 108 \times\right.\right. \\
\left.\left.\times 6,03 \cdot 10^{-4}\right)+5808\right)=0,25(\mathrm{M}) .
\end{gathered}
$$

10. Деформації в стиснутій та розтягнутій арматурі

$$
\begin{aligned}
\varepsilon_{\mathrm{s}}^{\prime} & =0,0052(0,25-0,05)=104 \cdot 10^{-5} ; \\
\varepsilon_{\mathrm{s}} & =0,0052(0,55-0,25)=156 \cdot 10^{-5} .
\end{aligned}
$$

11. Підставивши в умову (14)

$$
\left\{\begin{array}{l}
0<\varepsilon_{\mathrm{s}}=156 \cdot 10^{-5}<\varepsilon_{\mathrm{s} 0}=190 \cdot 10^{-5} \\
0<\varepsilon_{\mathrm{s}}{ }^{\prime}=104 \cdot 10^{-5}<\varepsilon_{\mathrm{s} 0}{ }^{\prime}=190 \cdot 10^{-5} .
\end{array}\right.
$$

Умова виконана. Розтягнута арматура дійсно працює в пружній стадії, стиснута арматура дійсно працює в пружній стадії.

\section{2. Знаходимо деформації в стиснутому бетоні $\varepsilon_{\mathrm{cl}}=0,25 \cdot 156 \cdot 10^{-5} /(0,55-0,25)=130 \cdot 10^{-5}$.}

13. Перевіряємо умову (25)

Умова виконується.

$$
\varepsilon_{\mathrm{cl}}=130 \cdot 10^{-5}<\varepsilon_{\mathrm{cu} . \mathrm{ck}}=320 \cdot 10^{-5} .
$$

14. Максимально допустимий момент при експлуатації

$$
\mathrm{M}_{\text {exp.u }}=5808 \cdot 0,25(0,55-0,25 \cdot 0,76)+
$$

$+104 \cdot 10^{-5} \cdot 2,1 \cdot 10^{8} \cdot 6,03 \cdot 10^{-4}(0,55-0,05)=588,57(\kappa \mathrm{H} \cdot \mathrm{M})$.

15. Перевіряємо умову (2)

$$
\mathrm{M}_{\mathrm{Ed}}=372,1 \kappa \mathrm{H} \cdot \mathrm{M}<\mathrm{M}_{\text {exp.u }}=588,57 \kappa \mathrm{H} \cdot \mathrm{M} \text {, }
$$

де $\mathrm{M}_{\mathrm{Ed}}=50 \cdot 12,22 / 8=372,1 \kappa \mathrm{H} \cdot \mathrm{м}$.

Отже, умова виконана. Жорсткість балки забезпечена.

Для перевірки отриманих результатів було розраховано $\mathrm{M}_{\text {Ехр.u }} 3$ використанням повної діаграми деформування матеріалів (рис. 2) [5]. 


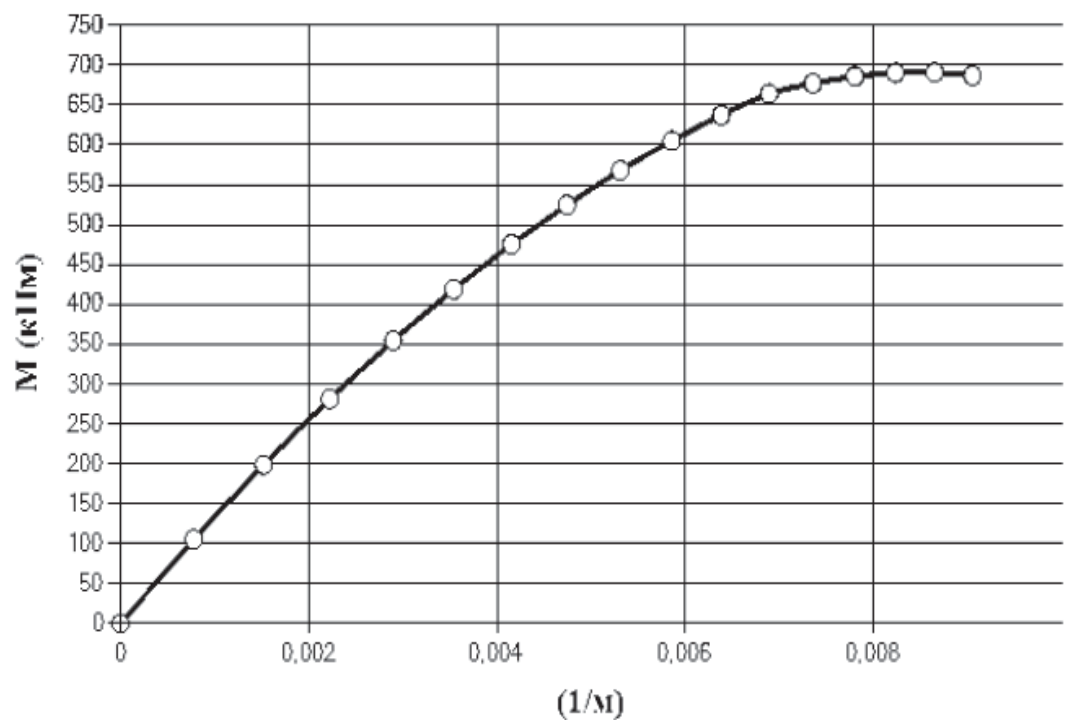

Рис. 2. Діаграма «момент-кривизна» за повною діаграмою деформування матеріалів

Згідно цього розрахунку максимальний момент при експлуатації $\mathrm{M}_{\text {Ехр.u }}=559,69$ кН·м при кривизні $(1 / \rho)_{\text {exp.u }}=0,0052(1 / \mathrm{M})$. Відносна похибка отриманих значень складає $-4,91 \%$.

\section{ВИСНОВКИ}

Розроблено методику розрахунку контролю прогинів із використанням спрощених діаграм деформування матеріалів.

Для оцінки достовірності розробленої методики було проведено розрахунки із використанням повної діаграми деформування. При порівнянні результатів встановлено, що використання такого методу дозволяє отримувати результати 3 відносною похибкою при низьких класах бетону $-8,5 \%$, при середніх класах бетону $-3,6 \%$, а при високих класах бетону $+2,9 \%$. Це говорить про достатню достовірність запропонованого алгоритму розрахунку для цілей, що передбачені у п. 7.4.4.1 [1].

Найдоцільніше запропонована методика може використовуватись при перевірці максимального прогину балок, в яких співвідношення $\mathrm{l} / \mathrm{h} \geq 20$, а процент армування перевищує 1,5\%.

Цю методику розрахунку можна використовувати як для експертних та перевірочних цілей при інженерному проектуванні залізобетонних конструкцій, так і при вивченні загального курсу iз дисципліни «Залізобетонні та армокам'яні конструкції» по спеціальності "Промислове та цивільне будівництво".

\section{БІБАІОГРАФІЧНИЙ СПИСОК}

1. Бетонні та залізобетонні конструкції. Основні положення: ДБН В.2.6-98:2009. - [Чинні від 2011-06-01]. - Київ: ДП «Укрархбудінформ», 2011. - 71 с. - (Держ. буд. норми України).
2. Будівлі та споруди спеціального призначення: сучасні матеріали та конструкції: робоча програма та тези доповідей, 24-25 травня 2018 р. - Київ: КНУБА, 2018. - 132 c.

3. Конструкції будинків і споруд. Бетонні та залізобетонні конструкції 3 важкого бетону. Правила проектування: ДСТУ Б В.2.6-156:2010. - [Чинний від 2011-06-01]. Київ: ДП «Укрархбудінформ», 2011. - 166 с. - (Нац. стандарт України).

4. Прогини i переміщення. Вимоги проектування: ДСТУ Б В.1.2-3:2006. - [Чинний від 2007-01-01]. - Київ: ДП «Укрархбудінформ», 2007. - 9 с. - (Нац. стандарт України).

5. Практичний розрахунок елементів залізобетонних конструкцій за ДБН В.2.6-98:2009 у порівнянні 3 розрахунками за СНиП 2.03.01-84* і EN 1992-1-1 (Eurocode 2) / [B.М. Бабаєв, А.М. Бамбура, О.М. Пустовойтова, та ін.] ; за заг. ред. B.С. Шмуклера. - Харків : Золоті сторінки, 2015. - 208 c.

Стаття надійшла до редакції 07.09.2018 р. 